His final conclusion: "Although it can be established that the vacillation of the Russian Marxists between different viewpoints followed a rather definite and recurrent pattern, the impression of instability remains. It is still a fact that changes of opinion followed each other in rapid succession and were, to all appearances, incalculable. ... What is the reason for this instability and incalculability? There is at least one explanation which appears to be more probable than speculations about the 'temperament' of the theorists. The explanation could be that the social reality which the Russian Marxists studied was in itself difficult to interpret and highly capricious" (pp. 358-59).

HenRy L. RoBerts Dartmouth College

\title{
EMPIRE AND REVOLUTION: A RADICAL INTERPRETATION OF CON- TEMPORARY HISTORY. By David Horowitz. New York: Random House, 1969. 274 pp. $\$ 7.50$.
}

Mr. Horowitz contends that socialist revolution is the only possible solution to "the continuing world-wide oppression of class, nation and race, the incalculable waste and untold misery, the unending destruction and preparation for destruction and the permanent threat to democratic order that characterize the rule of capitalism" (p. 258). He supports this claim by examining American efforts to halt the spread of communism, which he dates from President Wilson's decision to intervene in the Russian Civil War, by describing American exploitation of the Third World and even of its capitalist allies, and by devoting a very few pages to domestic affairs in the USSR and the United States. Horowitz assigns full responsibility for the cold war to the United States, even accepting the argument of Gar Alperovitz that President Truman used the atomic bomb on Japan in order to exert diplomatic pressure on the USSR.

This book performs two useful services: it presents in one short and readable volume the entire mythology of the revisionist historians of the "New Left," and it demonstrates the intellectual poverty on which that mythology rests. Horowitz never calculates the cost of socialist revolution in human lives, never mentions such unpleasant issues as the treatment of Jews in the USSR, of Tibetans by China, or of intellectuals in every Communist state, and never even tries to prove that life under contemporary socialism is in any way superior to life under capitalism. Rather than examine the significance of the Kronstadt Rebellion or the Tambov Revolt, Horowitz merely notes that the rule forbidding factions within the Bolshevik Party "was introduced as an expedient measure in a perilous situation at the end of the civil war" (p. 154). Rather than describe the Great Purges, Horowitz simply remarks that "the most repressive phase of the Russian development coincided with an external threat in the form of the rise of fascism" (p. 198). Although a Marxist, Horowitz displays none of Marx's concern for detailed knowledge, drawn from primary sources. Although heavily indebted to Trotsky, Horowitz lacks Trotsky's flashes of insight on the Bolshevik Party and the Stalinist regime.

A short review cannot attempt to correct all the errors of fact, interpretation, and omission which the reader will encounter in this work. Perhaps most irritating. however, to a student of Marxist ideology is the claim that a certain "misrepresentation of Marxism identifies it with a theory of history in which social development is seen as proceeding inexorably through discrete stages, from primitive communism 
to feudalism, capitalism and socialism. It is extremely doubtful whether Marx, himself, adhered to any such supra-historical theory, and it is certain that the Bolsheviks did not" (p. 21). If this claim were true, it would be difficult to explain why the CPSU still bothers to teach the doctrine of historical materialism. In fact, of course, Horowitz wrongly assumes that Lenin did not accept that conception of history which Marx described in A Contribution to the Critique of Political Economy. Lenin, in What the "Friends of the People" Are and How They Fight the Social Democrats, carefully quoted the passage from Marx which Horowitz evidently considers unimportant: "It is obvious that Marx's basic idea that the development of the social-economic formations is a process of natural history cuts at the very root of this childish morality which lays claim to the title of sociology. .... In broad outlines Asiatic, ancient, feudal, and modern bourgeois modes of production can be designated as progressive epochs in the economic formation of society."

Whether or not modern scholars accept their conclusions, Marx, Engels, Plekhanov, Lenin, and many prerevolutionary Russian radicals considered Russian society "Asiatic" or "semi-Asiatic" in nature. A number of scholars have discussed the problem of Russia's "Asiatic" institutional and cultural heritage, and have also dealt with the Marxist concept of the "Asiatic mode of production" as it concerns the various formulations of historical materialism-among them Karl Wittfogel, Stuart Schram, Samuel Baron, Shlomo Avineri, and the undersigned. It is doubly unfortunate that Horowitz overlooks this literature. He both misleads his readers about the complexity of Marxist social theory and fails to apply certain Marxist insights to his own analysis of Soviet history. For example, he fails to explain (either in Marxist or in any other terms) the survival and even the strengthening of bureaucracy under Lenin and Stalin. Horowitz contends that nationalism "can serve as a vehicle both for imperialist chauvinism and revolutionary self-determination ...., its bias (counterrevolutionary, revolutionary or reformist) being determined by the configuration of other social factors, particularly the balance of class forces" (p. 165). Yet in examining "the resurgence of Russian nationalism" (p. 140) Horowitz fails to indicate which type of nationalism Stalin resurrected or which social class caused its virulence.

No one can deny that tensions between classes and national power centers have characterized much of twentieth-century politics. A serious application of Marxist insights can be very helpful in discovering the basic trends of this phase of world history. The Leninist theory of imperialism, however, intellectually indefensible even at the time of its formulation, has failed to gain the necessary sophistication or empirical base to deal with the complexity of the modern world of politics and power, even as it has become increasingly comforting ideologically. This book will find many readers, thanks to the current popularity of national masochism and misunderstood Marxism. It will change few minds and enlighten none.

JoSePh SChiebel Georgetown University

THE RUSSIAN PRESENCE IN SYRIA AND PALESTINE, 1843-1914: CHURCH AND POLITICS IN THE NEAR EAST. By Derek Hoproood. Oxford: Clarendon Press, 1969. viii, 232 pp. $\$ 7.00$.

In the years 1843-1914 Russia's involvement in Syria and Palestine was a minor aspect of her policy toward the Ottoman Empire. Though the tsars had long been 